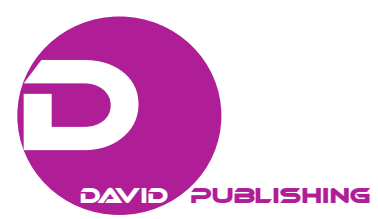

\title{
Measuring and Forecasting Retirement Portfolio Success
}

\author{
Craig L. Israelsen, Ph.D. \\ Submitted to the Journal of Statistical Science and Application \\ May 2017
}

The issue of retirement portfolio design and longevity is a compelling question that every retiree ponders. Obviously the answer is based on a number of variables, including the following:

(1) the performance of the retirement portfolio (i.e., the asset allocation model),

(2) initial withdrawal rate,

(3) annual cost-of-living adjustment (or COLA),

(4) extra withdrawals that may occur over the retiree's life,

(5) etc.

This article provides an overview of the simulated success of a retirement portfolio based on several of the variables listed above; namely the (a) asset allocation model of the retirement portfolio, (b) the initial withdrawal rate, and (c) the COLA.

As shown in Table 1, six different retirement asset allocation models are analyzed. There is a $100 \%$ cash model, a $100 \%$ US bond model, a $40 \%$ stock $/ 60 \%$ bond model, a $60 \%$ stock $/ 40 \%$ bond model, a multi-asset model that utilizes 12 indexes in equally weighted allocations, and finally a $100 \%$ large cap stock model. The non-diversified models (100\% cash, 100\% bonds, and 100\% stock) are not recommended, but simply included for comparison purposes.

The portfolio success rates in Table 1 are based on a $4 \%$ initial withdrawal rate and three different COLA's (3\%, 4\%, and 5\%). For example, a 4\% initial withdrawal rate would represent a first-year withdrawal of $\$ 40,000$ assuming a $\$ 1,000,000$ starting balance in the retirement portfolio. The second year withdrawal would be $\$ 41,200$ assuming a 3\% COLA; $\$ 41,600$ assuming a 4\% COLA; and $\$ 42,000$ assuming a 5\% COLA. The dollar amount withdrawn from the portfolio in subsequent years is simply a function of multiplying the prior year's withdrawal by the COLA.

The percentage figures in Table 1 represent the forecasted success of the retirement portfolio -where success is defined as the portfolio lasting at least 30 years. The forecasts are based on SimForecast ${ }^{\mathrm{TM}}$, an Excel-based simulation template designed by Sam Savage, Ph.D. and Craig Israelsen, Ph.D. Some may be familiar with Dr. Savage as the author of the book entitled "The Flaw of Averages" (John Wiley, 2012).

SimForecast ${ }^{\mathrm{TM}}$ uses actual historical data for a variety of market indexes to develop stochastic information packets (or SIPs) that are then utilized to generate forecasts of performance and retirement portfolio survival under various assumptions entered by the user.

The 18-year monthly returns from 1998-2015 for the following indexes were utilized in the analysis in this article: S\&P 500 Index, S\&P Midcap 400 Index, S\&P Small Cap 600 Index, MSCI EAFE Index, MSCI EM Index, Dow Jones US Select REIT Index, S\&P North American Natural Resources Sector Index, Deutsche Bank Liquid Commodity - Optimum Yield Index, Barclays US Aggregate Bond Index, Barclays U.S. TIPS 
Index, Barclays Global Treasury ex US Index, and 3-month US Treasury bills. The 18-year average annualized return of each index is shown below along with the standard deviation of annual returns over the 18 -year period from 1998-2015.

\begin{tabular}{lll}
\hline 18-Year Average Annualized Return & $\begin{array}{l}18-\text { Year Average Annualized } \\
\text { 12 Indexes (1998-2015) }\end{array}$ & $\begin{array}{l}\text { 18-Year Standard Deviation of } \\
\text { Annual Returns }\end{array}$ \\
\hline Large US Stock & $6.18 \%$ & $18.61 \%$ \\
Mid US Stock & $9.74 \%$ & $18.18 \%$ \\
Small US Stock & $8.67 \%$ & $17.72 \%$ \\
Non-US Dev Stock & $4.48 \%$ & $21.74 \%$ \\
Non-US Emerging Stock & $6.46 \%$ & $35.49 \%$ \\
Real Estate & $9.48 \%$ & $21.32 \%$ \\
Natural Resources & $5.13 \%$ & $24.09 \%$ \\
Commodities & $4.83 \%$ & $24.88 \%$ \\
US Bonds & $5.20 \%$ & $3.63 \%$ \\
TIPS & $5.66 \%$ & $6.42 \%$ \\
Non-US Bonds & $4.11 \%$ & $9.30 \%$ \\
Cash & $2.02 \%$ & $2.07 \%$ \\
12-Index Portfolio (equally weighted) & $7.05 \%$ & $12.43 \%$ \\
\hline
\end{tabular}

Let's consider a retirement portfolio consisting entirely of cash (90-day T-Bills). The forecasted success in Table 1 (where success is defined as the portfolio lasting at least 30 years during retirement) of an all-cash retirement portfolio is $0 \%$ using the assumption of a $4 \%$ initial withdrawal rate and three different COLA's. If moving to a $100 \%$ bond portfolio the forecasted success rate improves considerably: $96 \%$ forecasted success assuming a $4 \%$ withdrawal rate and a 3\% COLA. If the COLA moves to $4 \%$ the forecasted success rate drops to $71 \%$. Using a COLA of $5 \%$ the forecasted success rate plummets to $29 \%$--meaning that an all-bond portfolio survived in only $29 \%$ of the 1,000 SimForecast ${ }^{\mathrm{TM}}$ simulation trials.

It is interesting to note that the average annualized return of US bonds over the past 90 years (1926-2015) was $5.35 \%$ with a standard deviation of $5.71 \%$. Over the past 18 years from 1998 to 2015 US bonds produced an average annualized return of $5.20 \%$--which is remarkably similar to the 90 -year figure.

Table 1

Forecasted Portfolio Survival Rates for a 30-Year Retirement Period 1,000 Trials in SimForecast ${ }^{\mathrm{TM}}$ using 18-Year historical monthly data from 1998-2015

\begin{tabular}{|c|c|c|c|}
\hline Portfolio Model & $\begin{array}{l}\text { Percentage of Time Portfolio } \\
\text { Survived for at least } 30 \\
\text { Years } \\
3 \% \text { COLA }\end{array}$ & $\begin{array}{l}\text { Percentage of Time Portfolio } \\
\text { Survived for at least } 30 \\
\text { Years } \\
4 \% \text { COLA }\end{array}$ & $\begin{array}{l}\text { Percentage of Time Portfolio } \\
\text { Survived for at least } 30 \\
\text { Years } \\
5 \% \text { COLA }\end{array}$ \\
\hline $100 \%$ Cash & $0 \%$ & $0 \%$ & $0 \%$ \\
\hline $100 \%$ Bonds & $96 \%$ & $71 \%$ & $29 \%$ \\
\hline $40 \%$ Stock $/ 60 \%$ Bonds & $91 \%$ & $76 \%$ & $52 \%$ \\
\hline $60 \%$ Stock $/ 40 \%$ Bonds & $81 \%$ & $69 \%$ & $54 \%$ \\
\hline $\begin{array}{l}\text { 12-Asset Portfolio } \\
\text { (12-Asset classes equally weighted } \\
\text { resulting in a } 65 \% / 35 \% \text { model) }\end{array}$ & $87 \%$ & $78 \%$ & $66 \%$ \\
\hline $100 \%$ Large US Stock & $69 \%$ & $60 \%$ & $50 \%$ \\
\hline
\end{tabular}

$4 \%$ Initial Withdrawal Rate using various COLA's 
The forecasted success of a 40\% large cap US stock/60\% US bond portfolio was $91 \%$ assuming a $4 \%$ initial withdrawal rate and a 3\% COLA. Assuming a 4\% COLA, the forecasted success rate was 76\%, and with a $5 \%$ COLA a success rate of $52 \%$. As can be seen, as the COLA increases above $4 \%$ the only portfolios that have a forecasted success rate of $50 \%$ or higher are portfolios that include equity ingredients (40/60 model, 60/40 model, 12-asset model, 100\% stock model).

The retirement model with the highest forecasted success rate assuming a $4 \%$ initial withdrawal rate and a 4\% COLA was the multi-asset portfolio that included all 12 indexes in equal 8.33\% allocations (with annual rebalancing). The 12 -asset model is essentially a $65 \%$ growth and $35 \%$ fixed income model inasmuch as eight of the 12 asset classes are either equity or diversifiers while the remaining four ingredients are fixed income. The 12-asset retirement portfolio had a forecasted success rate of 78\% assuming a 4\% COLA and a forecasted success rate of $66 \%$ assuming a demanding COLA of 5\% (also the highest forecasted success rate among the various models). Clearly, a 5\% COLA presents quite a strain on a retirement portfolio.

A diversified retirement portfolio is clearly a logical starting point-particularly if considering cost-of-living adjustments in excess of 3\%--or initial withdrawal rates in excess of $4 \%$. For example, if the initial withdrawal rate is $5 \%$ (rather than $4 \%$ ) and the COLA is 3\%, the forecasted success rate of the $100 \%$ bond retirement portfolio falls from $96 \%$ to $38 \%$, whereas in the 12 -index diversified retirement model the forecasted success rate only declines from $87 \%$ to $70 \%$. Diversification-a core investing tenet during the pre-retirement years - should also prevail as a core tenet during the retirement years.

In Table 2 we examine only the diversified, 12-asset retirement portfolio under various withdrawal rate assumptions (from 1\% to 7\%) and varying COLA's (from $0 \%$ to $5 \%$ ). As in Table 1 , the figures in the body of the table represent the forecasted success rate of the portfolio lasting at least 30 years in retirement.

Clearly, a 7\% initial withdrawal rate combined with a 5\% COLA is unsustainable for any portfolio-even a diversified one. Based on 1,000 trials in SimForecast ${ }^{\mathrm{TM}}$ there was only an $8 \%$ success rate of the diversified 12 -asset portfolio lasting 30 years. Under a more reasonable set of assumptions (4\% withdrawal rate and 3\% COLA) the forecasted survival rate was $87 \%$ (as also shown in Table 1). Unlike Table 1 , we can observe in Table 2 what happens to the forecasted success rate under a variety of withdrawal rate and COLA assumptions.

Table 2

Forecasted Portfolio Survival of 12-Asset Portfolio for 30 Years 8.33\% Allocation to 12 Indexes Using 18 -Year historical monthly data from 1998-2015 1,000 Trials in SimForecast ${ }^{\mathrm{TM}}$

\begin{tabular}{|c|c|c|c|c|c|c|c|}
\hline & $\begin{array}{l}1 \% \text { Withdraw } \\
\text { Rate }\end{array}$ & $\begin{array}{l}2 \% \text { Withdraw } \\
\text { Rate }\end{array}$ & $\begin{array}{l}3 \% \text { Withdraw } \\
\text { Rate }\end{array}$ & $\begin{array}{l}\text { 4\% Withdraw } \\
\text { Rate }\end{array}$ & $\begin{array}{l}5 \% \text { Withdraw } \\
\text { Rate }\end{array}$ & $\begin{array}{l}6 \% \text { Withdraw } \\
\text { Rate }\end{array}$ & $\begin{array}{l}7 \% \text { Withdraw } \\
\text { Rate }\end{array}$ \\
\hline $\begin{array}{l}1^{\text {st }} \text { Year Withdrawal } \\
\text { (Assuming } \$ 1,000,000 \\
\text { starting balance) }\end{array}$ & $\$ 10,000$ & $\$ 20,000$ & $\$ 30,000$ & $\$ 40,000$ & $\$ 50,000$ & $\$ 60,000$ & $\$ 70,000$ \\
\hline \multicolumn{8}{|c|}{$\begin{array}{c}\text { Forecasted Success Rate of Retirement Portfolio Surviving at least } 30 \text { Years } \\
\text { Based on Various Withdrawal Rates and Cost-of-Living Adjustments }\end{array}$} \\
\hline $0 \%$ COLA & $100 \%$ & $100 \%$ & $100 \%$ & $99 \%$ & $95 \%$ & $82 \%$ & $68 \%$ \\
\hline $1 \%$ COLA & $100 \%$ & $100 \%$ & $100 \%$ & $98 \%$ & $88 \%$ & $74 \%$ & $54 \%$ \\
\hline $2 \% \mathrm{COLA}$ & $100 \%$ & $100 \%$ & $99 \%$ & $94 \%$ & $79 \%$ & $61 \%$ & $40 \%$ \\
\hline $3 \%$ COLA & $100 \%$ & $100 \%$ & $98 \%$ & $87 \%$ & $70 \%$ & $45 \%$ & $27 \%$ \\
\hline $4 \%$ COLA & $100 \%$ & $99 \%$ & $94 \%$ & $78 \%$ & $54 \%$ & $32 \%$ & $15 \%$ \\
\hline $5 \%$ COLA & $100 \%$ & $99 \%$ & $87 \%$ & $66 \%$ & $40 \%$ & $20 \%$ & $8 \%$ \\
\hline
\end{tabular}

Above $90 \%$ survival shaded in green 
The cells in the table with green shading represent success rates of $90 \%$ or higher. The southeast portion of Table 2 represents higher initial withdrawal rates combined with a larger COLA. As a result, forecasted retirement portfolio success declines.

For example, if a client has a $\$ 1$ million starting balance in their diversified 12-asset class retirement portfolio and they choose to withdraw $\$ 50,000$ in the first year of retirement (which amounts to a $5 \%$ withdrawal rate) AND they want to increase their annual withdrawal by $1 \%$ each year $(\$ 50,500$ in year 2 , $\$ 51,005$ in year 3, and so on) they have a forecasted success rate of $88 \%$--meaning that there is an $88 \%$ chance that they will still have money in their retirement portfolio 30 years later.

\section{Summary}

Forecasting the success (or failure) of a retirement portfolio 10, 20, or 30 years into the future is not a precise science - primarily because the actual sequence of experienced returns has a dramatic impact on the longevity of a retirement portfolio. Modeling how long a retirement portfolio will last involves events that we cannot completely manage or perfectly anticipate — even with very sophisticated mathematical techniques. The importance of tools such as SimForecast ${ }^{\mathrm{TM}}$ is that they allow us to consider a number of "what-if" scenarios by varying the initial withdrawal rate, the COLA, and the asset allocation model of the retirement portfolio. In essence, by using a modeling tool we begin to ask more--and often better--questions.

In spite of the natural challenges inherent in modeling future performance, the analysis presented here highlights characteristics of retirement portfolios that we can glean insight from. For instance, an all-cash or all-bond retirement portfolio has a limited chance of surviving 30 years if the retiree is withdrawing $4 \%$ or more of the portfolio balance and utilizing a COLA of 3\% or higher. A retirement portfolio needs "growth engines" such as equity-based mutual funds and diversifying asset classes that might include real estate and commodities funds. Also needed is a variety of fixed income asset classes that include US bonds, non-US bonds, inflation-protected bonds, and cash.

A broad mixture of asset classes, combined with a modest withdrawal rate and reasonable COLA, will provide the best chance for a retirement portfolio to outlast the retiree.

Craig L. Israelsen, $\mathrm{PhD}$, is an Executive-in-Residence in the Personal Financial Planning program in the Woodbury School of Business at Utah Valley University. He is the developer of the 7Twelve ${ }^{\circledR}$ Portfolio. Learn more about SimForecast and the 7Twelve ${ }^{\circledR}$ Portfolio at www.7TwelvePortfolio.com. 